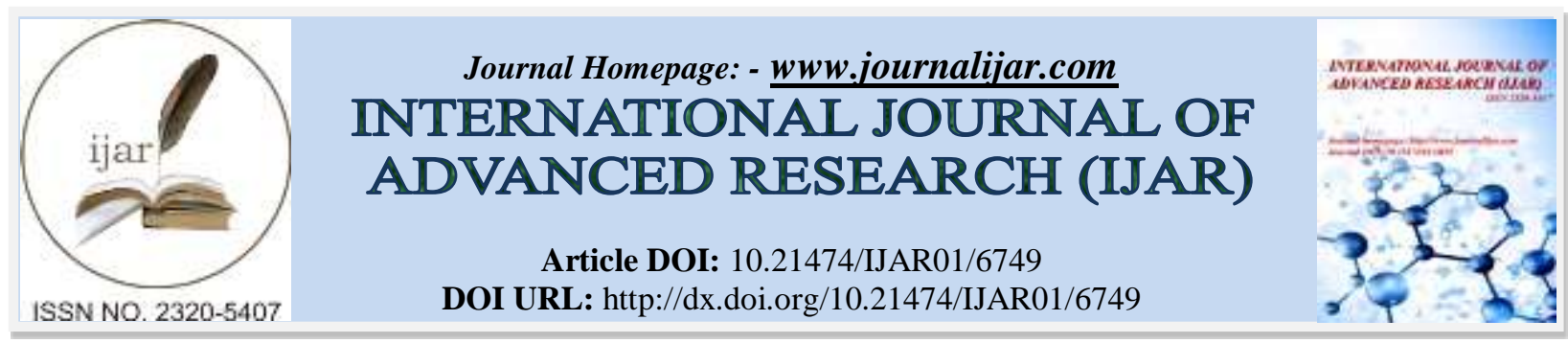

RESEARCH ARTICLE

\title{
THE EFFECT OF TREATMENT OF SEED STARCH OF JACKFRUIT (Arthocarpus heterophyllus Lamk) ON PHYSICAL QUALITY OF CHICKEN NUGGET.
}

1. Lecturer on Animal Husbandry, State Polythecnic of Jember.

2. Lecturer on Plantation Crops, State Polythecnic of Jember.

\section{Manuscript Info}

Manuscript History

Received: 15 January 2018

Final Accepted: 17 February 2018

Published: March 2018

Keywords:-

$\mathrm{pH}$, WHC, Tenderness, Microstructure.

\begin{abstract}
Research was conducted in the Laboratory of Animal Food Science and Technology and LSIH, University of Brawijaya, Malang, from June to July 2014. The aim of this research was to estimate physical quality (measured by $\mathrm{pH}$, WHC, Tenderness, Microstructure) of chicken nugget supplemented by jackfruit seed starch. Broiler meat from Merjosari market and jackfruit seed starch were used. The observed variable included $\mathrm{pH}, \mathrm{WHC}$, tenderness, and microstructure of chicken nugget. Data were analyzed with Randomized Block Design and it was continued with Duncan Test if there was a significant effect from each treatment. The result showed that there was a significant effect $(\mathrm{P}<0.01)$ from each treatment on $\mathrm{pH}$, WHC, tenderness, and microstructure, while chicken nugget with the best tenderness was obtained on P4 $(10,11 \mathrm{~N})$.
\end{abstract}

Copy Right, IJAR, 2018,. All rights reserved.

\section{Introduction:-}

Jackfruit seed is often discarded as a waste after fruit is consumed. Average weight of seed is one third of fruit, while other weight is represented by peel and flesh. Jackfruit seed waste, however, is nutritious. Every 100 gram of jackfruit seed has involved many nutrients, such as: $1.0 \mathrm{mg}$ iron matter; $0.20 \mathrm{mg}$ vitamin B1; 165 calories; 4.2 gram proteins; $0.1 \mathrm{mg}$ lipid; $36.7 \mathrm{mg}$ carbohydrates; $33.0 \mathrm{mg}$ calciums; $200 \mathrm{mg}$ phosphorous; $10 \mathrm{mg}$ vitamin C; and 56.7 gram waters. Chemical compounds of starch in jackfruit seed are very high, precisely around 40-50\%, which makes it potential to become source of starch.

Indonesian does not yet much utilize jackfruit seed starch as a food material. It is an ironic because jackfruit seed has a plentiful starch content and thus, it shall be a good alternative for food material substitution. The supplementation of jackfruit seed starch, in a form of flour, therefore, must give people a meaningful information about food diversification. This research is aimed to understand the positive effect of supplementation with jackfruit seed starch on quality of chicken nugget in terms of $\mathrm{pH}$, WHC, tenderness, and microstructure.

Some instruments are used in this research. The instrument for producing chicken nugget includes: meat grinder, table spoon, stove, big pan, wash basin, mold, knife, cutting board, and thermometer. The instrument for analysis involves: weighting bottle, analytical weight, oven, mortar, timer (stopwatch) and plastic. Other instruments that may be added to support the treatment process are porcelain dish, measuring glass, exicator, $35 \mathrm{~kg}$ load, glass, Whatman Paper No. 42, label paper, and graphic paper. 


\section{Method:-}

Treatment Design:-

Method of research is experiment with a design of Group Random Planning. This design involves 4 treatments and 5 replications. The grouping is done based on meat quality which has been different during the sampling. The factor to be observed is different treatment concentration of jackfruit seed starch on chicken nugget. The outline of treatment process is shown in Table 1.

Table 1:- Treatment Process Based on Group Random Planning

\begin{tabular}{|c|c|c|c|c|c|}
\hline \multirow[t]{2}{*}{ Treatment } & \multicolumn{5}{|c|}{ Group } \\
\hline & K1 & K2 & K3 & K4 & K5 \\
\hline P0 & P0K1 & P0K2 & P0K3 & P0K4 & P0K5 \\
\hline P1 & P1K1 & P1K2 & P1K3 & P1K4 & P1K5 \\
\hline P2 & P2K1 & $\mathrm{P} 2 \mathrm{~K} 2$ & $\mathrm{P} 2 \mathrm{~K} 3$ & P2K4 & $\mathrm{P} 2 \mathrm{~K} 5$ \\
\hline P3 & P3K1 & P3K2 & P3K3 & P3K4 & P3K5 \\
\hline P4 & P4K1 & $\mathrm{P} 4 \mathrm{~K} 2$ & P4K3 & P4K4 & P4K5 \\
\hline
\end{tabular}

Note:

$\mathrm{P}_{0} \quad$ : Treatment without jackfruit seed starch

$\mathrm{P}_{1} \quad$ : Treatment with jackfruit seed starch as $1 \%$ of 200 grams chicken meat

$\mathrm{P}_{2} \quad$ : Treatment with jackfruit seed starch as $2 \%$ of 200 grams chicken meat

$\mathrm{P}_{3} \quad$ : Treatment with jackfruit seed starch as $3 \%$ of 200 grams chicken meat

$\mathrm{P}_{4} \quad$ : Treatment with jackfruit seed starch as $4 \%$ of 200 grams chicken meat

\section{Research Variable:-}

There are variables to be observed in this research, and all of them refer to chemical quality of chicken nugget which is measured after treatment of jackfruit seed starch. The variables are:

a. $\mathrm{pH}$, tested with procedure of Hamm (1986)

b. WHC (water holding capacity), tested with procedure of Hamm (1986)

c. tenderness, tested with procedure of Syamsir (2007)

d. microstructure, tested with procedure of Priyatni (2011)

Table 2:- Chicken Nugget Formulation

\begin{tabular}{|l|l|l|l|l|l|}
\hline Material & $\mathrm{P} 0$ & $\mathrm{P} 1$ & $\mathrm{P} 2$ & $\mathrm{P} 3$ & $\mathrm{P} 4$ \\
\hline Jackfruit Seed Starch & $0 \%$ & $1 \%$ & $2 \%$ & $3 \%$ & $4 \%$ \\
\hline Tapioca Flour & $5 \%$ & $4 \%$ & $3 \%$ & $2 \%$ & $1 \%$ \\
\hline Ice Water & $14 \%$ & $14 \%$ & $14 \%$ & $14 \%$ & $14 \%$ \\
\hline Salt & $1 \%$ & $1 \%$ & $1 \%$ & $1 \%$ & $1 \%$ \\
\hline White Onion & $0.6 \%$ & $0.6 \%$ & $0.6 \%$ & $0.6 \%$ & $0.6 \%$ \\
\hline Pepper & $0.4 \%$ & $0.4 \%$ & $0.4 \%$ & $0.4 \%$ & $0.4 \%$ \\
\hline Meat & $79 \%$ & $79 \%$ & $79 \%$ & $79 \%$ & $79 \%$ \\
\hline Total & $100 \%$ & $100 \%$ & $100 \%$ & $100 \%$ & $100 \%$ \\
\hline
\end{tabular}

Data Analysis:-

The obtained data are tabulated. Significance value and standard deviation are analyzed with Analysis of Variance. If there is a significant difference of effect across treatments, the analysis proceeds with Duncan Test (Astuti, 2007).

\section{Result And Discussion:-}

Result of observation on physical quality of chicken nugget after treatment of jackfruit seed starch has been given in the following table.

Table 3:- Distribution of Physical Quality Test on Chicken Nugget After Treatment of Jackfruit Seed Starch at Different Concentration

\begin{tabular}{|c|c|c|l|}
\hline Treatment & $\mathrm{pH}$ & WHC $(\%)$ & Tenderness $(\mathrm{N})$ \\
\hline $\mathrm{P}_{0}(0 \%)$ & $6.21 \pm 0.04^{\mathrm{b}}$ & $50.64 \pm 1.63^{\mathrm{b}}$ & $12.86 \pm 0.45^{\mathrm{d}}$ \\
\hline $\mathrm{P}_{1}(1 \%)$ & $6.17 \pm 0.07^{\mathrm{b}}$ & $48.55 \pm 1.92^{\mathrm{ab}}$ & $11.71 \pm 0.49^{\mathrm{c}}$ \\
\hline
\end{tabular}




\begin{tabular}{|l|l|l|l|}
\hline $\mathrm{P}_{2}(2 \%)$ & $6.11 \pm 0.05^{\mathrm{ab}}$ & $47.29 \pm 1.61^{\mathrm{ab}}$ & $10.79 \pm 0.34^{\mathrm{b}}$ \\
\hline $\mathrm{P}_{3}(3 \%)$ & $6.08 \pm 0.09^{\mathrm{ab}}$ & $46.78 \pm 1.53^{\mathrm{a}}$ & $10.27 \pm 0.45^{\mathrm{ab}}$ \\
\hline $\mathrm{P}_{4}(4 \%)$ & $6.03 \pm 0.07^{\mathrm{a}}$ & $46.37 \pm 1.68^{\mathrm{a}}$ & $10.11 \pm 0.38^{\mathrm{a}}$ \\
\hline
\end{tabular}

Note: Different notation at similar column means that each treatment has very obvious difference $(\mathrm{P}<0.01)$.

The Effect of Treatment of Jackfruit Seed Starch During Nugget Preparation on pH of Chicken Nugget Table 3 indicates that the highest $\mathrm{pH}$ of chicken nugget is obtained from treatment without flour made of jackfruit seed starch $\left(\mathrm{P}_{0}\right)$, and the level of $\mathrm{pH}$ is $6.21 \pm 0.04$. The lowest $\mathrm{pH}$ level is $6.03 \pm 0.07$ which is derived from treatment with $4 \%$ jackfruit seed starch. This difference of $\mathrm{pH}$ level is caused by different chicken species and different percentage of jackfruit seed starch used in treatment. Syamsir (2007) has found that different pH level may be caused by different animal species and different percentage of flour concentration. The percentage of supplementation of jackfruit seed starch is inversely related with $\mathrm{pH}$ level. The greater percentage of jackfruit seed starch supplemented into treatment may reduce $\mathrm{pH}$ level because jackfruit seed starch is stronger in absorbing water.

The Effect of Treatment of Jackfruit Seed Starch During Nugget Preparation on WHC of Chicken Nugget Result shows that treatment of jackfruit seed starch has given very obvious effect $(\mathrm{P}<0.01)$ on WHC (water holding capacity) of chicken nugget. The distribution of test over the effect on chicken nugget's WHC from different concentration of jackfruit seed starch in treatment has been displayed in Table 3.

This table indicates that chicken nugget without supplementation of jackfruit seed starch $\left(\mathrm{P}_{0}\right)$ has a very obvious difference if compared to treatment of jackfruit seed starch at concentration of $1 \%\left(\mathrm{P}_{1}\right) ; 2 \%\left(\mathrm{P}_{2}\right) ; 3 \%\left(\mathrm{P}_{3}\right)$ and $4 \%$ $\left(\mathrm{P}_{4}\right)$. The combination between high protein from chicken meat and jackfruit seed starch has made chicken nugget treated with jackfruit seed starch becoming able or stronger in holding the water. Higher level of amylose content in the starch has given a characteristic of firmness to chicken nugget, while amylopectin content produces a characteristic of sticky. Soeparno (2005) said that water holding capacity (WHC) of meat protein is the ability of meat to hold the water or to retain the treated water during the effect of external process on meat, such as cutting, heating, grinding and pressing. Therefore, water absorption or gel-like capacity refers to the ability of meat to absorp water spontaneously from the liquid-contained environment.

\section{The Effect of Treatment of Jackfruit Seed Starch During Nugget Preparation on Tenderness of Chicken Nugget}

Result of variance analysis shows that treatment of jackfruit seed starch at different concentration during nugget preparation has produced very obvious different effect $(\mathrm{P}<0.01)$ on tenderness of chicken nugget. This difference is indicated by the decline of tenderness with the increase of concentration of jackfruit seed starch. The distribution of test over chicken nugget's tenderness after supplementation with jackfruit seed starch at different concentration has been shown also in Table 3.

As indicated by Table 3, means rate of chicken nugget's tenderness (N) is declining. The higher concentration is jackfruit seed starch in treatment, the lower will be the means rate of chicken nugget's tenderness $(\mathrm{N})$. The highest value of tenderness is $12.86 \pm 0.45 \mathrm{~N}$ obtained from treatment without jackfruit seed starch, or $0 \%\left(\mathrm{P}_{0}\right)$, whereas the lowest is $10.11 \pm 0.38 \mathrm{~N}$ derived from treatment with $4 \%$ jackfruit seed starch $\left(\mathrm{P}_{4}\right)$. The decline of tenderness value is obtained possibly due to the effect of gelatinization and also to the interaction between starch molecule and myofibrile protein. Moreover, the latter cause (the interaction) may have different level of effect due to different concentration of jackfruit seed starch (deMann, 1997). Treatment of jackfruit seed starch during chicken nugget preparation has reduced tenderness value of chicken nugget products, especially when the concentration of jackfruit seed starch is made to increase. Thus, it can be said that the less concentration is jackfruit seed starch in treatment, the more tenderness will be the chicken nugget. Mukprasirt and Sajjaanantakul (2003) have explained that jackfruit seed starch contains with $52.53 \%$ amylose and $67.2 \%$ amylopectin. These two substances are fractions of the starch which can be differentiated with hot water. The dissolved fraction is amylose, while the less dissolved fraction is amylopectin. Amylose has given a characteristic of firmness, while amylopectine produces a characteristic of stickiness (Winarno, 2008).

\section{The Effect of Treatment of Jackfruit Seed Starch During Nugget Preparation on Microstructure of Chicken} Nugget

Result of Scanning Electron Microscopy (SEM) on the nugget demonstrates that each treatment has given different effect on microstructure. Chicken nugget's microstructure of each treatment is displayed in Figure 1. 


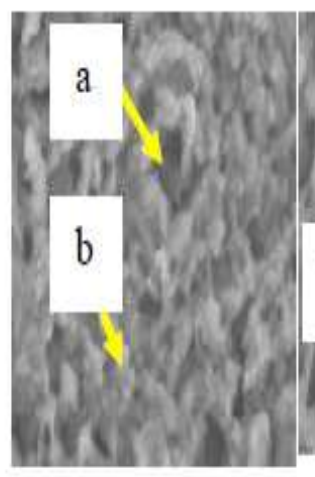

$\mathrm{PO}$

P1

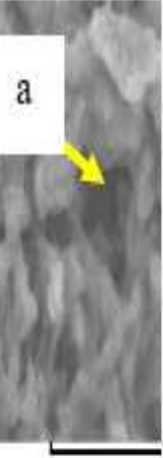

a
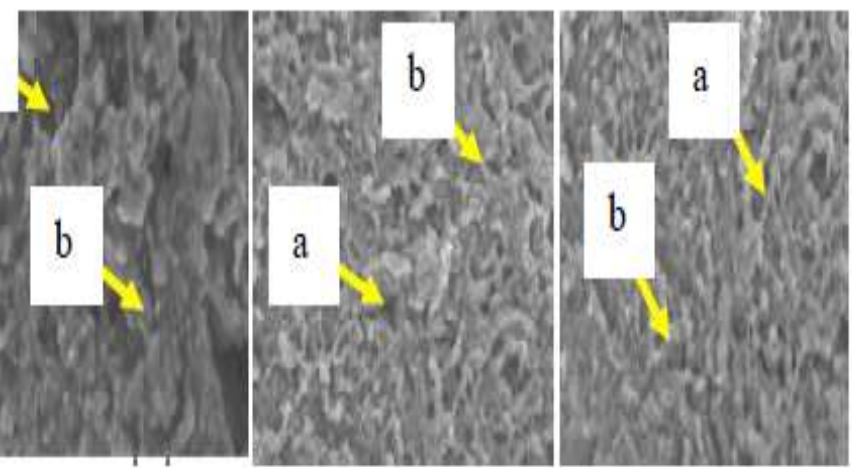

Figure 1:- Microstructure based on SEM with 600x Magnification

Note: (a) cavity and (b) matrix

Chicken nugget's microstructure in $\mathrm{P}_{0}$, representing a treatment without jackfruit seed starch, has shown a compact texture with few cavities, and it is evident possibly due to the presence of emulsion system in the nugget and also the function of protein as the emulsion agent. Fellows (2000) asserted that emulsion stability is very influential to the compactness of nugget texture keeping this texture to be more tender. Fiber particles may occupy the cavities, and this occupation changes the physical characteristic of texture, which is indicated by more tenderness. This process can be made coming true through a treatment without jackfruit seed starch. The lower level of gel strength and starch distribution may reduce compactness of gel structure. Firdevs (2004) said that fiber particles of food have greater size than those of tissue cells, which as a result, causing protein matrix to be less homogenous and also making the cavity to be more clearly seen. Rahardyan (2004) explained that tapioca granules are seen like solid grains which coalesce to each other to produce a food ball at bigger size than tissue cells. This process forces protein matrix to be less homogenous while also makes the cavities to be seen more clearly.

Chicken nugget's microstructure after treatment of jackfruit seed starch at concentration of $\mathrm{P}_{1}(1 \%), \mathrm{P}_{2}(2 \%), \mathrm{P}_{3}$ $(3 \%)$, and $\mathrm{P}_{4}(4 \%)$, has shown a compactness but many cavities are still apparent. The high number of cavity with different size represents a proof that chicken nugget is more tender. Walter (2000) gave assertion that there is interaction between meat protein and jackfruit seed starch, which means that protein matrix becomes more complex and shows different texture. The establishment of matrix between meat protein and jackfruit seed starch will produce a texture of elastic and thin. The production of this matrix is preceded by protein gelatinization.

Gelatinization and the binding between meat and starch have been exhibited in Figure 1, where the dough is experiencing a warming-up which evokes the process of protein denaturization which then creates cavities in the nugget. Antonio et.al., (2006) have noted that during denaturization process, globular proteins will crack open but without breaking the covalent bonds. Denaturized protein has few random shapes because it breaks polypeptide chains. In $\mathrm{P}_{4}$ treatment, gelatinization occurs. The size of starch granules at $\mathrm{P}_{4}$ treatment is bigger than those in other treatment because in $\mathrm{P}_{4}$ treatment, starch absorbs more waters. Walter (2000) stated that at temperature of $80-95^{\circ} \mathrm{C}$, starch granules have achieved optimum development, and by this condition, starch experiences gelatinization which then presses over the presence of protein matrix.

\section{Conclusion:- \\ Conclusion}

Treatment of jackfruit seed starch in the chicken nugget preparation can increase nugget quality. This increase has been obtained on the lowest $\mathrm{pH}$ value at $6.03 \pm 0.07$, the lowest WHC value at $46.37 \pm 1.68$, and the lowest value of tenderness at $10.11 \pm 0.38$. Microstructure that is smooth, evenly distributed, and with big size cavity, has given a great contribution to this research because it helps producing chicken nugget with the best tenderness. This condition is obtained from starch treatment at $4 \%\left(\mathrm{P}_{4}\right)$. 


\section{Suggestion}

Based on the result of research, it is suggested that treatment of jackfruit seed starch at concentration of $4 \%$ in 200 grams chicken meat shall be considered as a priority in the preparation of chicken nugget.

\section{References:-}

1. Astuti, M. 2007. Pengantar Ilmu Statistik untuk Peternakan dan Kesehatan Hewan. Binasti. Bogor.

2. Antonio. M, J. Carnendan P and Eduardo. 2006. Mortadella Sausage Formulations with Mechanically Separated Layer Hen Meat Preblended with Antioxidant. Piracicaba. Brazil. 63: 240-245

3. DeMan, J. M. 2007. Kimia Makanan. Edisi kedua.Institut Teknologi Bandung. Bandung.

4. Fellows, P. J. 2000. Food Processing Technology. Ellis Horwood, New York. Padmawinata. Penerbit ITB. Bandung.

5. Firdevs, S. 2004. Effect Of Different Batter Formulations On Quality Of Deep-Fat Fried Chicken Nugget. A Review, Thesis. Food Science.

6. Hamm, R. 1986. Functional Properties of the Myofibrillar System and Their Measurement in Muscle as Food.Academic Press. New York.

7. Priyatni, A. 2011.Petunjuk Praktis Mikroskop Elektron. UNAIR. Surabaya.

8. Soeparno. 2005. Ilmu dan Teknologi Daging. Gadjah Mada University Press. Yogyakarta.

9. Syamsir, E. 2007.Pengaruh pH daging terhadap mutu (teknologi) daging. http://ilmu pangan.blogspot. com/2008/08/pengaruh $\mathrm{pH}$ daging terhadap mutu. Html.

10. Walter, J. 2000. Microstructure Research As A Basis For Engineered. National Regional Research Laboratory Agricultural Research Service. Peoria.

11. Widyastuti, E. S. 1998. Morfologi dan Tekstur Bakso Daging Sapi dengan Bahan Pengisi Tapioka dan Pati Kentang Modifikasi.Skripsi. Fakultas Peternakan. Universitas Brawijaya. Malang.

12. Winarno, F.G. 2008. Kimia Pangan dan Gizi. Gramedia Pustaka Utama. Jakarta. 